\title{
Variasi Zooplankton di Kolam Budi Daya Ikan Air Tawar di Kabupaten Minahasa Provinsi Sulawesi Utara
}

\author{
(Zooplankton Variation in Freshwater Fish Pond in North Minahasa Regency of \\ North Sulawesi Province)
}

\begin{abstract}
Tince Rumaseb
Mahasiswa Program Studi Budidaya Peraikan FPIK Unsrat

Email: tatiensumaseb@yahoo.com
\end{abstract}

\begin{abstract}
Zooplankton variation in fresh water fish pond on North Minahasa District of North Sulawesi Province was done in five different areas. The goal is to evaluate the variation and the abundance of zooplankton. The result is copepod is the first rank in abundance ( $50 \%$ on April and 51\% on August), followed by cladoceran (32\% on April and 33\% on August) and finally, rotifer (18\% on April and 16\% on August).
\end{abstract}

Keywords : zooplankton, fish pond, fresh water, variation, abundance

\section{PENDAHULUAN}

Keberadaan zooplankton telah menjadi sangat penting untuk menunjang populasi ikan di kolam pemeliharaan. Kelompok ini merupakan faktor utama dalam mentransfer energi antara fitoplankton dan ikan. Studi atau kajian terhadap zooplankton ini dapat memberi faedah dalam merencanakan serta menentukan suksesnya usaha perkolaman ikan air tawar.

Telah diketahui, secara umum bahwa ikan adalah komoditas yang relatif murah sebagai makanan sumber protein, dan untuk spesies tertentu, sudah menjadi komoditas perdagangan yang penting sebagai sumber devisa negara seperti ikan sidat. Keberhasilan yang dicapai ikan untuk tumbuh secara sehat sangat tergantung oleh air yang juga dipengaruhi oleh beberapa faktor, diantaranya faktor biologi.

Pemeliharaan ikan atau budi daya atau akuakultur dalam kolam harus memenuhi kondisi yang menyebabkan plankton bertumbuh khususnya zooplankton. Dinamika nutrien serta material dalam areal perkolaman sangat ditentukan oleh sumber yang masuk ke dalam kolam serta interaksi antara faktorfaktor biotik dan abiotik (Bhatnagar and Devi, 2013).

Zooplankton mengandung nutrisi yang penting untuk larva ikan serta berperan penting dalam rantai makanan, dimana zooplankton menduduki tropik level kedua sebagai konsumer pertama dan berperan langsung pada tropik level berikutnya. Interaksi antara parameter fisika-kimia dari kualitas air serta 
produksi plankton dalam kolam ikan akan sangat menentukan keberhasilan pemeliharaan ikan. Karena peran zooplankton ini maka studi "Variasi zooplankton di kolam budidaya ikan air tawar, Kabupaten Minahasa Utara, Provinsi Sulawesi Utara” dilakukan.

\section{METODE PENELITIAN}

\section{Sampling}

Sampling dilakukan pada bulan April dan bulan Agustus, tahun 2014 pada kolam-kolam pemeliharaan ikan di daerah Rumah makan Teterusan (A), Tetei (B), Airmadidi (C), Tatelu (D) dan Talawaan (E). Kolam-kolam ini dipilih secara random dari keseluruhan unit perkolaman yang ada di daerah Kabupaten Minahasa Utara. Pengambilan zooplankton dilakukan dengan plankton net berukuran $80 \mu \mathrm{m}$. Parameter kualitas air yang diukur adalah suhu dan $\mathrm{pH}$.

\section{Analisis}

Pengamatan dan identifikasi zooplankton dilakukan dengan mikroskop menurut Shiel (1995) dan Shuters and Rissik (2009). Kepadatan zooplankton dihitung menurut formula oleh Clesceri et al. (1989) sebagai berikut:

Dimana:

$$
\mathrm{E}=\frac{C \cdot A}{F a \cdot V}
$$

$$
\begin{aligned}
\mathrm{E}= & \text { Jumlah zooplankton } \\
\mathrm{C}= & \text { Jumlah zooplankton yang } \\
& \text { dihitung } \\
\mathrm{A}= & \text { Volume total sampel } \\
\mathrm{Fa}= & \text { Volume sub sampel } \\
\mathrm{V}= & \text { Volume air yang tersaring }
\end{aligned}
$$

\section{Persentase Kelimpahan}

Untuk menghitung persentase kelimpahan digunakan rumus menurut Boyd (1979) dalam Rukminasari $d k k$. (2012) yaitu,

Persentase kelimpahan $(\%)=\frac{\mathrm{ni}}{\mathrm{N}} \times 100 \%$

Dimana,

ni: Jumlah individu setiap jenis yang teramati

$\mathrm{N}$ : Jumlah total individu

Tabel 1. Hasil pengukuran suhu dan $\mathrm{pH}$ beberapa kolam ikan

\begin{tabular}{|c|l|c|c|c|c|}
\hline \multirow{2}{*}{ Kolam } & \multirow{2}{*}{ Lokasi } & \multicolumn{2}{|c|}{ Suhu $\left({ }^{\circ} \mathrm{C}\right)$} & \multicolumn{2}{c|}{$\mathrm{pH}$} \\
\cline { 3 - 6 } & & April & Agustus & April & Agustus \\
\hline A & Rumah makan Teterusan & 26 & 26 & 7 & 7 \\
\hline B & Tetei & 25 & 25 & 7 & 7 \\
\hline C & Aermadidi & 25 & 25 & 7 & 7 \\
\hline D & Tatelu & 25 & 25 & 7 & 7 \\
\hline E & Talawaan & 25 & 25 & 7 & 7 \\
\hline
\end{tabular}


Tabel 2. Variasi dan jumlah zooplankton pada areal perkolaman

\begin{tabular}{|l|c|c|c|c|c|c|c|c|c|c|}
\hline $\begin{array}{l}\text { Zooplankton } \\
\text { (individu/L) }\end{array}$ & \multicolumn{9}{|c|}{ April } & \multicolumn{7}{c|}{ Agustus } \\
\hline & A & B & C & D & E & A & B & C & D & E \\
\hline Rotifer & - & 15 & 28 & 12 & 56 & - & 1 & 10 & 4 & 12 \\
\hline Kopepoda & 13 & 61 & 102 & 57 & 90 & 5 & 6 & 26 & 14 & 32 \\
\hline Kladosera & - & 28 & 98 & 32 & 48 & - & 7 & 20 & 6 & 21 \\
\hline
\end{tabular}

Tabel 3. Persentase kelimpahan zooplankton

\begin{tabular}{|c|c|c|c|c|c|c|c|c|c|c|c|c|c|c|}
\hline \multirow{2}{*}{$\begin{array}{l}\text { Zooplankton } \\
\text { (individu/L) }\end{array}$} & \multicolumn{5}{|c|}{ April } & \multirow[t]{2}{*}{$\sum$} & \multirow[t]{2}{*}{$\%$} & \multicolumn{5}{|c|}{ Agustus } & \multirow[t]{2}{*}{$\sum$} & \multirow[t]{2}{*}{$\%$} \\
\hline & A & B & $\mathrm{C}$ & $\mathrm{D}$ & $E$ & & & A & $\mathrm{B}$ & $\mathrm{C}$ & $\mathrm{D}$ & $E$ & & \\
\hline Rotifer & - & 15 & 28 & 12 & 56 & 111 & $18 \%$ & - & 1 & 10 & 4 & 12 & 27 & $16 \%$ \\
\hline Kopepoda & 13 & 61 & 102 & 57 & 90 & 323 & $50 \%$ & 5 & 6 & 26 & 14 & 32 & 83 & $51 \%$ \\
\hline Kladosera & - & 28 & 98 & 32 & 48 & 206 & $32 \%$ & - & 7 & 20 & 6 & 21 & 54 & $33 \%$ \\
\hline & & & & & $\sum$ & 640 & & & & & & $\sum$ & 164 & \\
\hline
\end{tabular}

\section{HASIL DAN PEMBAHASAN}

\section{Kualitas air}

Hasil pengukuran parameter suhu dan $\mathrm{pH}$ dari beberapa kolam ikan dapat dilihat pada Tabel 1. Dari hasil ini dapat dikatakan tidak terdapat variasi yang besar bagi suhu dan $\mathrm{pH}$ pada kolamkolam yang diukur.

\section{Variasi zooplankton}

Organisme zooplankton yang diperoleh adalah rotifer, kopepoda dan kladosera. Kepadatan dari ketiga jenis zooplankton ini dapat dilihat pada Tabel 2 dan presentase kelimpahan ketiga jenis zooplankton dapat dilihat pada Tabel 3.

Sampel zooplankton yang diambil baik pada bulan April maupun bulan Agustus 2017 didominasi oleh kopepoda, dengan presentasi kelimpahan 50\% pada bulan April dan 51\% pada bulan Agustus. Boxshall and Defaye (2008) menyatakan bahwa organisme ini menempati hampir seluruh habitat air tawar, serta merupakan komponen utama dalam komunitas plankton. Namun keragaman spesies terbesar ditemukan pada habitat perairan laut (10.186 spesies).

Zooplankton berikutnya yang menempati urutan kedua pada habitat perkolaman saat sampling adalah cladocera. Cladocera yang teridentifikasi adalah famili daphnidae dan dari family chydoridae. Hessen et al. (2003) dalam Shah and Pandit (2013) menyatakan bahwa cladocera juga merupakan zooplankton dengan biomas yang besar serta berfungsi sebagai elemen yang penting dalam rantai makanan perairan tawar. Cladocera juga mengontrol kepadatan alga sehingga dapat dijadikan sebagai indicator kualitas perairan.

Zooplankton yang menempati jumlah terkecil dari unit perkolaman yang 
disampling adalah rotifer. Rotifer bersama kopepod dan cladocera, merupakan zooplankton utama yang penting dalam ekosistim perairan tawar (Segers, 2008). Ketiga jenis zooplankton ini sangat berperan penting dalam peningkatan usaha budidaya baik untuk ikan konsumsi maupun untuk kultur ikan hias.

Zooplankton merupakan sumber makanan yang penting bagi biota budi daya. Zooplankton berperan sangat penting untuk beberapa hal seperti (1) transfer energi yang dimulai dari phytoplankton, dan (2) mengontrol produksi phytoplankton. Zooplankton sangat dibutuhkan sebagai pakan larva maupun juvenil. Untuk itu maka siklus reproduksi, pertumbuhan, reproduksi serta laju kelangsungan hidupnya sangat berhubungan dengan produksi biomas ikan.

Ada banyak faktor yang menentukan kelimpahan zooplankton seperti ketersediaan cahaya, suhu dan distribusi nutrien. Variasi zooplankton juga ditentukan oleh karakteristik hidrokimia air, bentuk perkolaman, tersedianya tanaman air dan predator. Bervariasinya faktor biotik dan abiotik juga menentukan distribusi zooplankton. Pengukuran parameter kualitas air seperti suhu $\left(25^{\circ} \mathrm{C}-26^{\circ} \mathrm{C}\right)$ dan $\mathrm{pH}$ (7), menunjukkan bahwa kondisi perairan lokasi perkolaman berada dalam kondisi baik untuk pertumbuhan zooplankton. Beenamma and Sadanand (2011) menyatakan bahwa parameter kualitas air sangat menentukan variasi serta kelimpahan zooplankton.

Variasi dan kelimpahan zooplankton dari hasil sampling di areal perkolaman, juga merupakan hasil integrasi dari pemupukan dan adanya aktifitas pemeliharaan ternak. Kebanyakan kolam menerima secara langsung limbah air dari aktifitas peternakan. Hal ini dapat dilihat secara langsung adanya kandang-kandang ternak di sekitar unit perkolaman.

\section{KESIMPULAN}

Adapun kesimpulan yang dapat diambil dari hasil penelitian ini adalah kopepoda merupakan zooplankton (50\% di bulan April dan 51\% di bulan Agustus) yang menempati urutan pertama dalam kelimpahan diikuti oleh cladocera (32\% di bulan April dan 33\% di bulan Agustus) dan rotifer (18\% di bulan April dan 16\% di bulan Agustus).

\section{DAFTAR PUSTAKA}

Beenamma and Sadanand (2011). Monthly changes in the abundance and biomass of zooplankton and water quality parameters in Kukkarahalli Lake of Mysore, India. J. Environ. Biol., 32, p. 551-557.

Bhatnagar A. and Devi P. 2013. Water quality guidelines for the management of pond fish culture. International Journal of Environmental Sciences, Vol. 3, No. 6, p. 1980-2009.

Boxshall GA and Defaye D. 2008. Global diversity of copepods (Crustacea: Copepoda) in freshwater. Hydrobiologia, 595, p. 195-207.

Clesceri LS, Greeenberg AE and Eaton AD. 1989. Standard Methods for the Examination of Water and Wastewater. $20^{\text {th }}$ ed. Washington 
D.C., American Public Health Assoc., American Water Works Assoc., and Water Environment Fed.

Rukminasari N, Daud T. dan Muh. Ilham B., 2012. Kelimpahan dan Struktur Komunitas Zooplankton di Perairan Pulau Samalona, Kota Makassar, Provinsi Sulawesi Selatan. Seminar Nasional Tahunan IX : Hasil Penelitian Perikanan dan Kelautan, Yogyakarta 14 Juli 2012.

Segers H. 2008. Global diversity of rotifers (Rotifera) in freshwater. Hydrobiologia, 595, p. 49-59
Shah J.A. and Pandit A.K., 2013. Diversity and Abundance of Cladoceran Zooplankton in Wular Lake, Kashmir Himalaya. Research Journal of Environmental and Earth Sciences, 5, 7, p. 410-417.

Shiel RJ. 1995. A guide to identification of rotifers, cladocerans and copepods from Australians inland waters. Cooperative Research Centre for Freshwater Ecology, Ellis Street, Thurgoona. 150 p.

Shuters IM and Rissik D. 2009. Plankton: A guide to their ecology and monitoring for water quality. CSiro Publishing, Australia. 273 p. 